\title{
Modified hydrated sodium silicate as a modern binder for ecological moulding sands
}

Katarzyna Major-Gabryś, Stanisław M. Dobosz, Jarosław Jakubski

AGH University of Science and Technology, Faculty of Foundry Engineering, Department of Moulding Materials, Mould Technology and Foundry of Non-ferrous Metals, Al. A. Mickiewicza 30, 30-059 Krakow, Poland, katmg@agh.edu.pl

This article is devoted to ecological moulding sands with hydrated sodium silicate as binder. The inorganic nature of the binder results in poor knock-out properties and low ability to mechanical reclamation of tested moulding sands. In the present study authors focused on developing a new addition to the composition of these environmental friendly foundry moulding sands, providing them better knock-out properties. The analysis of the literature data let authors focus on the use of additives containing $\mathrm{Al}_{2} \mathrm{O}_{3}$ as components of moulding sands with hydrated sodium silicate. These additives provide better knock-out properties of moulding sands measured according to retained strength $R_{c}{ }^{\text {tk }}$ and also lead to lower thermal expansion of moulding sands. The authors have developed a new supplement containing $\mathrm{Al}_{2} \mathrm{O}_{3}$ and demonstrated its positive impact on moulding sand with hydrated sodium silicate knock-out properties.

Keywords: moulding sand, hydrated sodium silicate, phase gamma $\mathrm{Al}_{2} \mathrm{O}_{3}\left(\gamma-\mathrm{Al}_{2} \mathrm{O}_{3}\right.$ phase), thermal expansion, knockout properties

\section{Acknowledgements}

Scientific research financed from AGH, No 11.11.170.318-3.

\section{References}

[1] DOBOSZ, ST.M., JELINEK, P., MAJOR-GABRYŚ, K. (2011). Development tendencies of moulding and core sands, China Foundry, Vol. 8, No. 4, pp. 438-446.

[2] MAJOR-GABRYŚ, K., DOBOSZ ST.M. (2007). High-temperature expansion and knock-out properties of moulding sands with water glass. Archives of Foundry Engineering. Vol. 7, No. 1, pp.127-130.

[3] DOBOSZ, ST.M., MAJOR-GABRYŚ, K. (2008). The mechanism of improving the knock-out properties of moulding sands with water glass. Archives of Foundry Engineering. Vol. 8, No. 1, pp.37-42.

[4] SYČEV, I.S.(1965). Polučenije lehkovybijernych smešej. Litejnoje Proizvodstvo, No. 6 pp. 31-37. (in Russian)

[5] JELINEK, P. (1968) Vliv $\mathrm{Al}_{2} \mathrm{O}_{3}$ na rozpadavost CT - smesi. Sbornik vedeckych praci Vysoke skoly banske $v$ Ostrave, Vol. 14, No. 6, pp. 75-102. (in Czech)

[6] JELINEK, P. (2004). Pojivove soustavy slevarenskych formovacich smesi. (in Czech)

[7] LEVIN, E.M., ROBBINS, C.R., MCMURDIE, H.F. (1964). Phase Diagram for Ceramists, Columbus, Ohio, USA

[8] BIELAŃSKI A. (2002): Podstawy chemii nieorganicznej. Part 2. . Polish Scientific Publishers PWN. Warsaw. (in Polish)

[9] KOLDITZA, L. (1994). Inorganic Chemistry (Chemia nieorganiczna). Part 1. Polish Scientific Publishers PWN. Warsaw. (in Polish)

[10] PAGLiA, G. (2004). Determination of the Structure of $\gamma$-Alumina using Empirical and First Principles Calculations combined with Supporting Experiments. Faculty of Science. Department of Applied Physics and Department of Applied Chemistry. Curtin University of Technology.

[11] KRYUKOVA, G.N., KLENOV, D.O., IVANOVA, A.S., TSYBULYA, S.V. (2000). Vacancy ordering in the structure of $\gamma-\mathrm{Al}_{2} \mathrm{O}_{3}$. Journal of European Ceramic Society, No. 20, pp. 1187-1189.

[12] JAYARAM, V., LEVI, C.G. (1989). The structure of $\delta$-alumina evolved from the melt and the $\gamma-\delta$ transformation. Acta Metallurgica, Vol. 37, No. 2, pp. 569-578.

[13] WANG, X., XU, X., CHOI, S.U.S. (1999). Thermal conductivity of nanoparticle-fluid mixture, Journal of Thermophysics and Heat Transfer, Vol.13, No. 4, pp. 474-480.

[14] LIPPENS, B.C., DE BOER, J.H. (1964). Study of phase transformations during calcination of aluminum hydroxides by selected area electron diffraction, Acta Crystallographica., Vol. 17, No. 10, pp. 1312-1321.

[15] STACHOWICZ, M., GRANAT, K., NOWAK, D. (2011). Influence of $\alpha-\mathrm{Al}_{2} \mathrm{O}_{3}$ on residual strength of 
microwave-hardened moulding sands with water-glass, Archives of Foundry Engineering, Vol. 11, No 2, pp. 203-208. (in Polish)

[16] CORBETT, J., RIEMER, O. (2004). Nanotechnology and Its Place in Modern Production, Manufacturing Technology, Vol. 4, October 2004, pp. 23-27.

[17] VOJTĚCH, D., MICHALCOVA, A., KNOTEK, V., MAREK, I. (2012). Study of nano-crystalline metals prepared by selective chemical leaching, Manufacturing Technology, Vol. 12, No 13, pp. 292-296. 